\title{
Ethanol Extract of Punica granatum L. Leaf in Combination with Gallic acid Ameliorates Liver Dysfunction in High-fat Diet-induced Obese Rats
}

\author{
SREEDEVI PRABHAKAR RAO AND VIJAYALAKSHMI KRISHNAMURTHY* \\ Department of Biochemistry, Bharathi Women's College, George Town, Chennai-600 108, India
}

Rao et al.: Hepatoprotective Activity of Punica granatum L. Leaf Extract in combination with Gallic acid

\begin{abstract}
The present study was designed to evaluate the hepatoprotective activity of ethanol extract of Punica granatum $\mathrm{L}$. leaf in association with gallic acid in high-fat diet-induced animal model. Total 30 rats were used. These were divided into 5 groups of 6 animals each. Group 1 was given normal diet and was treated as the control. Group 2 was given a high-fat diet and was considered as induced group. Groups 3, 4 and 5 were given high-fat diet along with ethanol extract of Punica granatum $\mathrm{L}$. leaf (200 mg/kg), ethanol extract of Punica granatum L. leaf + gallic acid $(100+10 \mathrm{mg} / \mathrm{kg})$ and orlistat $(22 \mathrm{mg} / \mathrm{kg})$, which constituted the treatment groups. The total period of the study was $8 \mathrm{w}$. At the end of the study, activities of alanine aminotransferase, aspartate aminotransferase, alkaline phosphatase, total protein, albumin, globulin and albumin/globulin ratio were measured. The antioxidant defence activities like superoxide dismutase, catalase and reduced glutathione were analysed together with lipid peroxidation in the liver tissue. In addition, histology of liver was examined. The high-fat diet caused alternation in the activities of markers of liver function along with changes in histology of the liver. The high-fat diet increased lipid peroxidation and decreased antioxidant defence system. The alterations induced by the high-fat diet were restored more effectively by the ethanol extract of Punica granatum L. leaf+gallic acid than the ethanol extract of Punica granatum L. leaf alone or orlistat.
\end{abstract}

Key words: High fat diet, ethanol extract of Punica granatum L. leaf, gallic acid, orlistat, liver

Obesity is a chronic metabolic disorder resulting from an imbalance between energy intake and expenditure and causes alterations in lipid metabolism. It is a highly prevalent condition that requires to be solved throughout the world ${ }^{[1]}$. The consequences of obesity lead to cardiovascular disease, pulmonary dysfunction, diabetes, colon cancer and metabolic syndrome and thus it is one of the highest risk factors for multiple organ dysfunction ${ }^{[2]}$. During the progress of obesity, serum fatty acid and hepatic lipogenesis is increased, which causes fatty liver, impaired liver function and eventually liver failure ${ }^{[3]}$.

During obesity, adipose tissue similar to macrophages secretes a variety of inflammatory mediators such as interleukin-6, leptin and tumour necrosis factor. These mediators induce the production of reactive oxygen species (ROS), which generate the process known as oxidative stress $^{[4]}$. Free radicals have unpaired electrons in an outer orbit, are generated during several metabolic reactions like obesity ${ }^{[5]}$. The primary targets

*Address for correspondence E-mail: viji42research@yahoo.co.in

July-August 2019 of ROS are cell membrane polyunsaturated fatty acids (PUFA), which in turn lead to damage in the cell structure and function ${ }^{[6]}$. In addition, obesity impairs the enzyme antioxidant system, which causes depletion of superoxide dismutase (SOD), catalase (CAT), glutathione reductase (GR) and glutathione peroxidase (GPx) activities and also impairs the non-enzymatic oxidative system comprising of reduced glutathione content or GSH, vitamins and minerals ${ }^{[7]}$.

The liver is the major site of insulin action, which plays a central role in the maintenance of systemic lipid and glucose homeostasis and therefore it is easily susceptible to the oxidative stress ${ }^{[8]}$. An excess amount of ROS has detrimental effects on hepatocytes

This is an open access article distributed under the terms of the Creative Commons Attribution-NonCommercial-ShareAlike 3.0 License, which allows others to remix, tweak, and build upon the work non-commercially, as long as the author is credited and the new creations are licensed under the identical terms

Accepted 02 June 2019

Revised 27 February 2019

Received 06 November 2018

Indian J Pharm Sci 2019;81(4):673-680 
by damaging DNA, lipids and proteins, which lead to disruptions in cellular homeostasis and aggravating features of the metabolic syndrome ${ }^{[9]}$, which may be associated with exacerbated nutrient oxidation ${ }^{[10]}$. Therefore, the intake of antioxidants is necessary to suppress hepatic oxidative stress in order to maintain hepatic homeostasis, which is important not only for improving insulin action in the liver, but also for eliminating insulin resistance elsewhere in the body.

Antiobesity drugs reduce nutrient absorption by affecting lipid mobilization and utilization. To date, these drugs are unable to regulate the weight gain completely, which have limited tolerability and adverse effects. Indian traditional herbal medicine provides effective solutions without major side effects. Therefore, alternative therapy, especially based on natural products with minimal side effects is necessary. From the beginning of the last century, extracts and active molecules from natural origin have been developed for the treatment of obesity and several studies in obese humans and animals suggested that phytochemicals have significant antiobesity effects ${ }^{[1]}$.

Foods rich in polyphenols (e.g. anthocyanins, flavonols) play an important role in the reduction of lipids in serum and liver by decreasing the expression of lipogenic genes ${ }^{[12]}$. These are also involved in the prevention and control of complications arising from oxidative stress by increasing the circulation of antioxidant compounds ${ }^{[13]}$ because these can neutralize reactive species, due to their favourable number and position of hydroxyl groups ${ }^{[14]}$.

Punica granatum, generally known as pomegranate, is a deciduous tree belongs to the family Punicaceae. Therapeutically beneficial pomegranate constituents include ellagic acid, ellagitannins (punicalagins, punicalin, punicafolin), punicic acid, flavonoids, anthocyanidins, anthocyanins, flavonols, flavone glycosides and flavone ${ }^{[15]}$. A previous high performance liquid chromatography study confirmed the presence of gallic acid (GA) in the ethanol extract of Punica granatum leaf (EPGL $)^{[16]}$. GA is a natural phenolic agent endowed with antioxidant, antiinflammatory, anticancer, and free radical scavenging activities ${ }^{[17]}$. In spite of worldwide use of pomegranate against various diseases, no studies are found for evaluating its effect on high-fat diet (HFD)-induced acute hepatic damage. Therefore, the present study was aimed to investigate the possible protective effects of EPGL and GA in the liver by analysing serum biochemical parameters and histopathological studies together with liver oxidative stress parameters induced by HFD in Wistar albino rats.

\section{MATERIALS AND METHODS}

$P$. granatum leaves were collected from around the Sathyavedu village, Andhra Pradesh and were authenticated in the National Institute of Herbal science, Plant Anatomy Research Centre, Chennai (PARC/2017/3381). EPGL was prepared using ethanol using Soxhlet apparatus ${ }^{[18]}$. GA was obtained from Sigma-Aldrich (Chennai, India). Orlistat was purchased from Stanley Hospital, Chennai. All other chemicals and reagents used were of analytical grade.

\section{Diet preparation (Kim et al. $\left.{ }^{[19]}\right)$ :}

Normal diet (ND, $5 \%$ fat) was general rat pellets, purchased from Sri Sai Feeds, Bangalore. It consists of concentrate (300 g), corn (600 g), vitamins and minerals $(50 \mathrm{~g})$, which are in the proportion of $65 \%$ carbohydrate, (60\% starch and $5 \%$ sucrose), $5 \%$ fat, $20 \%$ crude protein, $5 \%$ fibre and $5 \%$ vitamins and minerals. It provides $2813 \mathrm{kcal}$ energy per $\mathrm{kg}$ of food. HFD (35\% fat) was used to induce obesity in rats. It was prepared by mixing $30 \%$ lard and $5 \%$ sunflower oil to ND, which are in the proportion of $40 \%$ carbohydrate (35\% starch and $5 \%$ sucrose), $35 \%$ fat, $20 \%$ crude protein and $5 \%$ vitamins and minerals. This diet provides $5130 \mathrm{kcal}$ energy per $\mathrm{kg}$ of food. HFD was prepared freshly in order to prevent lipid autoxidation.

\section{Acute oral toxicity study of EPGL:}

Acute oral toxicity of EPGL was studied in Zebra fish at the maximum dose of $1000 \mathrm{mg} / \mathrm{kg}$ as per the OECD (Organisation for Economic Cooperation and Development) guidelines, 420 (2001). Adverse behaviour or mortality was observed within $4 \mathrm{~d}$ after dosing ${ }^{[20]}$. Hence 100 and $200 \mathrm{mg} / \mathrm{kg}$ of extract were selected as the doses to use in this study.

\section{Experimental design and grouping:}

In this study, 30 Wistar rats weighing around $150 \pm 20 \mathrm{~g}$ were used, which were procured from the Centre for Laboratory Animal Technology and Research, Sathyabama University, Chennai. All animals were housed in plastic cages with 6 rats in each cage. Rats were maintained under controlled temperature $\left(25^{\circ}\right)$ with 40-60 \% humidity and 12:12 h light/dark cycle. Rats were allowed free access to tap water and normal pellet diet. The rats were acclimatized under these 
conditions for $2 \mathrm{w}$ prior to the commencement of the experiment. The animal handling procedures and the study design were approved by the Institutional animal ethical committee (Approval number: SU/CLATR/ IAEC/IX/068/2017). Experiments were initiated after the 30 male Wistar rats were randomly assigned into 2 groups, one fed with standard diet (control, $n=6$ ) and the remaining fed with HFD, $(n=24)$ to induce obesity. Rats fed with HFD were considered as obese when their body weight significantly increased when compared to control ${ }^{[21]}$.

After $1 \mathrm{w}$, the HFD fed animals $(\mathrm{n}=24)$ were equally divided into 4 groups (6 animals in each group), according to the treatments received for the remaining $7 \mathrm{w}$ of the study period. The final 5 groups were as follows, group 1- fed with ND and distilled water (vehicle) for $8 \mathrm{w}(\mathrm{n}=6)$, group 2- fed with HFD and distilled water (vehicle) for $8 \mathrm{w}(\mathrm{n}=6)$, group 3- fed with HFD (8 w) and EPGL (200 mg/kg, orally, $7 \mathrm{w}$ ), group 4- fed with HFD (8 w), EPGL (100 mg/kg, orally, $7 \mathrm{w})+\mathrm{GA}(10 \mathrm{mg} / \mathrm{kg}$, orally, $7 \mathrm{w})$ and group 5- fed with HFD (8 w) and orlistat (22 mg/kg, orally, $7 \mathrm{w})$.

After $8 \mathrm{w}$, the animals were starved overnight, anesthetized with sodium pentobarbital given intraperitoneally. Blood samples were collected from the retro-orbital plexus and centrifuged at $2500 \mathrm{rpm}$ for $15 \mathrm{~min}$ at $30^{\circ}$ for serum preparation. The following parameters were measured in the serum: alanine aminotransferase (ALT), aspartate aminotransferase (AST), alkaline phosphatase (ALP), total protein (TP) and albumin. After collecting the blood, animals were sacrificed by cervical dislocation, and then their liver was immediately excised by dissection, washed in icecold saline, blotted individually on filter paper. A small portion of the liver from each group was homogenized and used to determine SOD, CAT, GSH and malondialdehyde (MDA). The remaining part of the liver from each group was used for histopathological studies.

\section{Preparation of tissue homogenate:}

A $10 \% \mathrm{w} / \mathrm{v}$ liver homogenate was prepared in $0.15 \mathrm{M}$ potassium chloride buffer and centrifuged at $8000 \mathrm{rpm}$ for $10 \mathrm{~min}$. The supernatant was used for the estimation of MDA and CAT. A $10 \% \mathrm{w} / \mathrm{v}$ liver homogenate was prepared using $0.25 \%$ sucrose in $5 \mathrm{M}$ phosphate buffer and centrifuged at $8000 \mathrm{rpm}$ for $10 \mathrm{~min}$. The supernatant solution was used for estimation of SOD and $\mathrm{GSH}^{[22]}$.

\section{Histopathological examination:}

A portion of the liver tissue was used for histopathological examination. Tissues were fixed in $10 \%$ buffered formalin ( $\mathrm{pH} 7.2$ ), dehydrated, cleared and embedded in paraffin wax. About 3 to $4 \mu \mathrm{m}$ sections were made using a microtome and after staining with hematoxylin-eosin, the sections were moulded in DPX and observed under a light microscope ${ }^{[23]}$.

\section{Liver function test:}

Protein content of the samples were assayed according to the method of Lowry et al. ${ }^{[24]}$ and serum albumin was determined by the method of Doumas et al. ${ }^{[25]}$. Serum globulin and albumin/globulin $(\mathrm{A} / \mathrm{G})$ ratio were determined using calculation ${ }^{[26]}$. The activities of ALT and AST were assayed using the method of Reitman and Frankel ${ }^{[27]}$. The estimation of ALP activity was done based on the method of King and Armstrong ${ }^{[28]}$.

\section{Superoxide dismutase (SOD) activity:}

The SOD activity was determined according to the method of McCord and Fridovich ${ }^{[29]}$. The homogenate $(0.01 \mathrm{ml})$ was mixed with $0.2 \mathrm{ml}$ of $0.1 \mathrm{M}$ EDTA (containing $0.0015 \%$ sodium cyanide), $0.1 \mathrm{ml}$ of $1.5 \mathrm{mM}$ nitoblue tetrazolium (NBT, prepared in $67 \mathrm{mM}$ phosphate buffer, $\mathrm{pH} 7.8$ ) and $0.05 \mathrm{ml}$ of riboflavin. All the tubes were incubated at RT for $15 \mathrm{~min}$ and absorbance of the blue colour formed was measured against distilled water at $560 \mathrm{~nm}$. Percent inhibition was calculated after comparing the absorbance of the sample with the absorbance of control (the tube containing no enzyme). One unit of enzyme activity was taken as the enzyme reaction, which gave $50 \%$ inhibition of NBT reduction in one min and expressed in $\mathrm{U} / \mathrm{mg}$ of tissue.

\section{Catalase (CAT) activity:}

The CAT activity was determined using the Goth et al. method $^{[30]}$ for the determination of hydrogen peroxide $\left(\mathrm{H}_{2} \mathrm{O}_{2}\right)$, which forms a stable complex with ammonium molybdate that absorbs at $405 \mathrm{~nm}$. The CAT activity of tissue homogenate was determined according to the following procedure. Four test tubes were taken and labelled as S (sample), B1 (blank 1), B2 (blank 2) and B3 (blank 3). The tissue homogenate $(50 \mu \mathrm{l})$ was added to $\mathrm{S}$ and $\mathrm{B} 1$ tubes. Then $1 \mathrm{ml}$ of substrate $(65 \mu \mathrm{mol} / \mathrm{ml}$ $\mathrm{H}_{2} \mathrm{O}_{2}$ in $60 \mathrm{mmol} / \mathrm{l}$ sodium potassium phosphate buffer, $\mathrm{pH}$ 7.4) was added to all tubes except B3. About $50 \mu 1$ of phosphate buffer $(60 \mathrm{mmol} / 1$ sodium potassium phosphate buffer, $\mathrm{pH}$ 7.4) was added to $\mathrm{B} 2$ 
and B3. All tubes were incubated at $37^{\circ}$ for $60 \mathrm{~s}$. The enzymatic reaction was stopped by the addition of $1.0 \mathrm{ml}$ ammonium molybdate $(32.4 \mathrm{mM})$. The yellow colour complex of molybdate and $\mathrm{H}_{2} \mathrm{O}_{2}$ was measured at $405 \mathrm{~nm}$ against B3. One unit, CAT decomposes $1 \mu \mathrm{mol}$ of $\mathrm{H}_{2} \mathrm{O}_{2} / \mathrm{min}$ under the assay conditions. CAT activities are expressed as a kilo unit per litre $(\mathrm{kU} / \mathrm{l})^{[31]}$. CAT activity was calculated by CAT activity $(\mathrm{kU} / \mathrm{l})=$ A (B1)-A (sample)/A(B2)-A(B3) $\times 271$, where, B1 = control, B2 = standard, B3 = reagent blank and $271=$ constant.

\section{Reduced glutathione (GSH) activity:}

GSH activity was measured using the Moron et al. ${ }^{[31]}$ method. About $0.5 \mathrm{ml}$ of tissue homogenate was mixed with $0.1 \mathrm{ml}$ of $25 \%$ trichloro acetic acid (TCA) and kept on ice for a few min. Afterwards, these were subjected to centrifugation at $3000 \mathrm{rpm}$ for a few min to settle the precipitate. About $0.1 \mathrm{ml}$ of the supernatant was mixed with $2.4 \mathrm{ml}$ of $0.1 \mathrm{~mol}$ phosphate buffer $(\mathrm{pH}$ 7.4) and $0.5 \mathrm{ml}$ of $10 \mathrm{mM}$ dithionitrobenzene (DTNB was prepared in $0.2 \mathrm{~mol}$ phosphate buffer, $\mathrm{pH} 8$ ). The yellow color formed was measured after $10 \mathrm{~min}$ at 412 nm against a blank, which consists of $0.1 \mathrm{ml}$ of $5 \%$ TCA. GSH content was calculated as $\mu$ mol DTNB conjugate formed/gram tissue using a molar extinction coefficient of $13.6 \times 10^{3} / \mathrm{mol} / \mathrm{cm}$ with the help of a formula ${ }^{[31]}$.

\section{Malondialdehyde (MDA) assay:}

The level of lipid peroxidation in the tissue was measured as MDA according to the method of Ohkawa et al. ${ }^{[32]}$. About $4 \mathrm{ml}$ of reaction mixture $(0.4 \mathrm{ml}$ of the tissue homogenate, $1.5 \mathrm{ml}$ of $0.8 \%$ thiobarbituric acid, $1.5 \mathrm{ml}$ of $20 \%$ acetic acid (pH 3.5) and $0.6 \mathrm{ml}$ of distilled water) was kept in a boiling water bath at $95^{\circ}$ for $1 \mathrm{~h}$. After $1 \mathrm{~h}$, the reaction mixture was removed from the water bath and cooled. Then $1 \mathrm{ml}$ of distilled water and $5 \mathrm{ml}$ of butanol:pyridine mixture (15:1) was added to the reaction mixture. It was mixed well and centrifuged at $3000 \mathrm{rpm}$ for $10 \mathrm{~min}$. Absorbance of the clear supernatant was measured at $532 \mathrm{~nm}$ against butanol:pyridine mixture ${ }^{[32]}$.

\section{Statistical analysis:}

Results were expressed as mean \pm standard deviation. One-way analysis of variance (ANOVA) and Post Hoc tests were used for the analysis and comparison of data within and between groups with SPSS software (IBM, 20). The difference between the groups is considered as significant at $\mathrm{p} \leq 0.05$.
Wide spread of obesity has become a global health problem because it is associated with dietinduced complications such as metabolic syndrome, cardiovascular disease, non-alcoholic fatty liver disease (NAFLD) and increased risk of developing chronic kidney disease ${ }^{[33]}$. HFD-induced obesity in animals is considered as a good model as they reported to bear close resemblance with human obesity ${ }^{[34]}$.

Table 1 showed the results of liver function tests in rats. The liver is the one of the largest organ of the body, which plays a major role in lipid and glucose metabolism ${ }^{[35]}$. According to the two-hit hypothesis, after an initial hit (hepatic steatosis), the second hit (inflammation) takes place to develop NAFLD. In support of the above hypothesis, the liver of obese rats displayed characteristic features of hepatic steatosis such as accumulation of fat and swelling of rough endoplasmic reticulum and mitochondria in hepatocytes ${ }^{[36]}$. Since the liver plays a major role in the detoxification of compounds so liver function test is an essential criteria for evaluating its activity ${ }^{[37]}$. The healthy liver also plays a major role in protein metabolism, so any alterations in protein concentration may be associated with the liver disease. During liver disease, the TP and albumin concentrations may be decreased due to inadequate synthesis ${ }^{[38]}$. ALT, AST and ALP have been regarded as reliable markers of liver function ${ }^{[39]}$. Elevation in the activities of these enzymes could be due to a variety of conditions like muscle, intestinal and hepatic injury ${ }^{[40]}$. Many reports showed that the activities of ALT, AST and ALP were elevated in blood during HFD-induced hepatic damage ${ }^{[41]}$. Accordingly, in our present study, HFD fed rats showed decreased concentration of TP, albumin and increased activities of hepatic enzymes, which indicated that the liver function is impaired. Treatment with EPGL (group 3), EPGL + GA (group 4) and orlistat (group 5) showed a non-significant (NS) difference with group 1 in TP. But in case of albumin, globulin and $\mathrm{A} / \mathrm{G}$ ratio, group 4 only showed a NS difference with group 1. Regarding liver enzyme activities, both group 3 and 4 showed a NS difference in ALP with group 1 but the treatment with orlistat (group 5) showed significant difference with group 1. But in other enzyme activities like ALT and AST, group 4 only showed a NS difference with group 1. A previous report revealed that ALP activity was increased due to the effect of whole body fat mass, whereas elevated ALT activity was related to abdominal obesity ${ }^{[42]}$. Another study reported that the abdominal 
obesity was associated with an increased risk of nonalcoholic steatohepatitis $(\mathrm{NASH})^{[43]}$. From these it could be concluded that $\mathrm{EPGL}+\mathrm{GA}$ was found to be effective in restoring liver function more effectively than EPGL and orlistat.

Table 2 depicted the oxidative stress of HFD-induced rat liver. Oxidative stress is an imbalance between ROS and antioxidants. Increased oxidative stress is a common phenomenon in obesity. Chronic oxidative stress in obesity leads to diabetes and cardiovascular disease ${ }^{[7]}$. Oxidative stress causes functional impairment in liver due to increased nutrient oxidation and also it depends upon the type of diet ${ }^{[44]}$. These data suggested that the proinflammatory state of obese individuals might be probably related to chronic excessive nutrient intake ${ }^{[45]}$. CAT and SOD are enzymatic antioxidants while glutathione is a non-enzymatic antioxidant; they all exert synergistic effects in scavenging free radicals ${ }^{[46]}$. SOD, the natural cellular antioxidant enzyme, plays a pivotal role in oxygen defence metabolism by intercepting and reducing superoxide to molecular oxygen and $\mathrm{H}_{2} \mathrm{O}_{2}{ }^{[47]}$. CAT is also an antioxidant enzyme located in peroxisomes and decomposes $\mathrm{H}_{2} \mathrm{O}_{2}$ to $\mathrm{H}_{2} \mathrm{O}$ and $\mathrm{O}_{2}{ }^{[48]}$. GSH is one of the major antioxidant produced by the cells, participating directly in the neutralization of free radicals and reactive $\mathrm{O}_{2}$ compounds as well as maintaining exogenous antioxidants such as vitamin $\mathrm{C}$ and $\mathrm{E}$ in their reduced (active) forms ${ }^{[49]}$. All these defensive antioxidant enzymes work in conjugation with each other, and thus these are able to protect from free radicals-mediated oxidative injury/damage.
Numerous oxygenated compounds, mainly aldehydes such as MDA, are produced during the attack of free radicals on membrane lipoproteins and PUFA. Assay of MDA is probably the most common method for the measurement of lipid peroxidation ${ }^{[50]}$. This is revealed that there was a significant increase in the levels of MDA and the significant decrease in hepatic SOD, CAT and GSH in the obese rats. However, concomitant administration of EPGL and GA has led to more increase in SOD, CAT and GSH than other groups. Similar to the present study, Kumar et al., also observed an increase in SOD and CAT in rat liver homogenate by the administration of the Zizyphus jujuba fruit extract in paracetamol-induced liver damage ${ }^{[51]}$. The level of MDA was significantly increased in the HFD fed group as compared to control. It was decreased in all treatment groups, but well advanced in group 4 as it showed NS difference with group 1 in MDA. Results of the present investigation showed that EPGL+GA not only regulated SOD and CAT but also the nonenzymatic defence system (GSH) and alleviated lipid peroxidation more effectively than EPGL and orlistat.

The liver periportal region of all groups was shown in fig. 1. Group 1 showed normal periportal region composed of portal vein, bile duct and hepatic artery surrounded by cords of hepatocytes. No inflammation and fibrosis were observed in group 1 (control). Group 2 showed moderate periportal inflammation composed of lymphocytes, plasma cells and eosinophils, which indicated that HFD-induced inflammation. Group 3, 4 and 5 showed mild periportal inflammation composed

TABLE 1: EFFECT OF EPGL, GA AND ORLISTAT ON LIVER FUNCTION IN HIGH FAT DIET-INDUCED OBESE RATS

\begin{tabular}{lccccc}
\hline Parameters (units) & Group 1 & Group 2 & Group 3 & Group 4 & Group 5 \\
\hline Total protein $(\mathrm{g} / \mathrm{dl})$ & $8.9 \pm 0.1$ & $8.5 \pm 0.1$ & $8.96 \pm 0.152$ & $8.93 \pm 0.15$ & $8.86 \pm 0.15$ \\
Albumin $(\mathrm{g} / \mathrm{dl})$ & $3.4 \pm 0.2$ & $2.46 \pm 0.05$ & $3.1 \pm 0.1^{a^{* * *}}$ & $3.3 \pm 0.1$ & $3.16 \pm 0.05^{\mathrm{a} * *}$ \\
Globulin $(\mathrm{g} / \mathrm{dl})$ & $5.5 \pm 0.1$ & $6 \pm 0.11$ & $5.86 \pm 0.057^{\mathrm{b} * * *}$ & $5.63 \pm 0.05$ & $5.7 \pm 0.1^{\mathrm{a} * *}$ \\
A/G ratio & $0.62 \pm 0.05$ & $0.4 \pm 0.01$ & $0.53 \pm 0.01$ & $0.586 \pm 0.015$ & $0.55 \pm 0.005$ \\
AST (IU/l) & $34.3 \pm 1.52$ & $73 \pm 4.58$ & $46 \pm 3$ & $37.3 \pm 1.15$ & $44 \pm 1$ \\
ALT (IU/l) & $47 \pm 4.58$ & $91.6 \pm 5.68$ & $66 \pm 1$ & $51.6 \pm 3$ & $60.6 \pm 1.52$ \\
ALP (IU/l) & $192 \pm 7.21$ & $272 \pm 12.28$ & $201.3 \pm 10.96$ & $197.3 \pm 8.32$ & $234.6 \pm 4.5$ \\
\hline
\end{tabular}

EPGL- ethanol extract of Punica granatum L. leaf; GA - gallic acid; HFD - high fat diet; A/G ratio - albumin/globulin ratio; AST - aspartate transaminase; ALT - alanine transaminase; ALP - alkaline phosphatase. $a=$ group 3, 4 and 5 (treatment groups) compared with group 1 whereas $b=$ group 3,4 and 5 (treatment groups) compared with group $2 .{ }^{* * *}$ Denotes significant $(\mathrm{p} \leq 0.05)$

TABLE 2: EFFECT OF EPGL, GA AND ORLISTAT ON ANTIOXIDANT STATUS IN HFD-INDUCED OBESE ANIMAL LIVER

\begin{tabular}{lccccc}
\hline Parameters (Units) & Group 1 & Group 2 & Group 3 & Group 4 & Group 5 \\
\hline GSH $(\mu \mathrm{mol} / \mathrm{g})$ & $8.6 \pm 0.43$ & $4.52 \pm 0.22$ & $7.22 \pm 0.52$ & $7.59 \pm 0.33$ & $7.57 \pm 0.19$ \\
CAT $(\mathrm{kU} / \mathrm{l})$ & $50.26 \pm 0.9$ & $21.59 \pm 1.96$ & $42.56 \pm 0.651$ & $50 \pm 1$ & $48.7 \pm 1.56$ \\
SOD $(\mathrm{U} / \mathrm{mg}$ tissue) & $2 \pm 0.011$ & $0.65 \pm 0.002$ & $1.65 \pm 0.014$ & $1.756 \pm 0.005$ & $1.176 \pm 0.005$ \\
MDA $(\mu \mathrm{mol} / \mu \mathrm{g})$ & $6.9 \pm 0.42$ & $9.69 \pm 0.66$ & $8 \pm 0.633^{\mathrm{a} * * *}$ & $7.13 \pm 0.33$ & $8.39 \pm 0.717 \mathrm{a} * * * \mathrm{~b} * * *$ \\
\hline
\end{tabular}

EPGL - ethanol extract of Punica granatum L. leaf; GA - gallic acid; HFD - high-fat diet; a = group 3, 4 and 5 (treatment groups) compared with group 1 whereas $b=$ group 3,4 and 5 (treatment groups) compared with group 2 , ${ }^{* * *}$ denotes significant $(p \leq 0.05)$ 

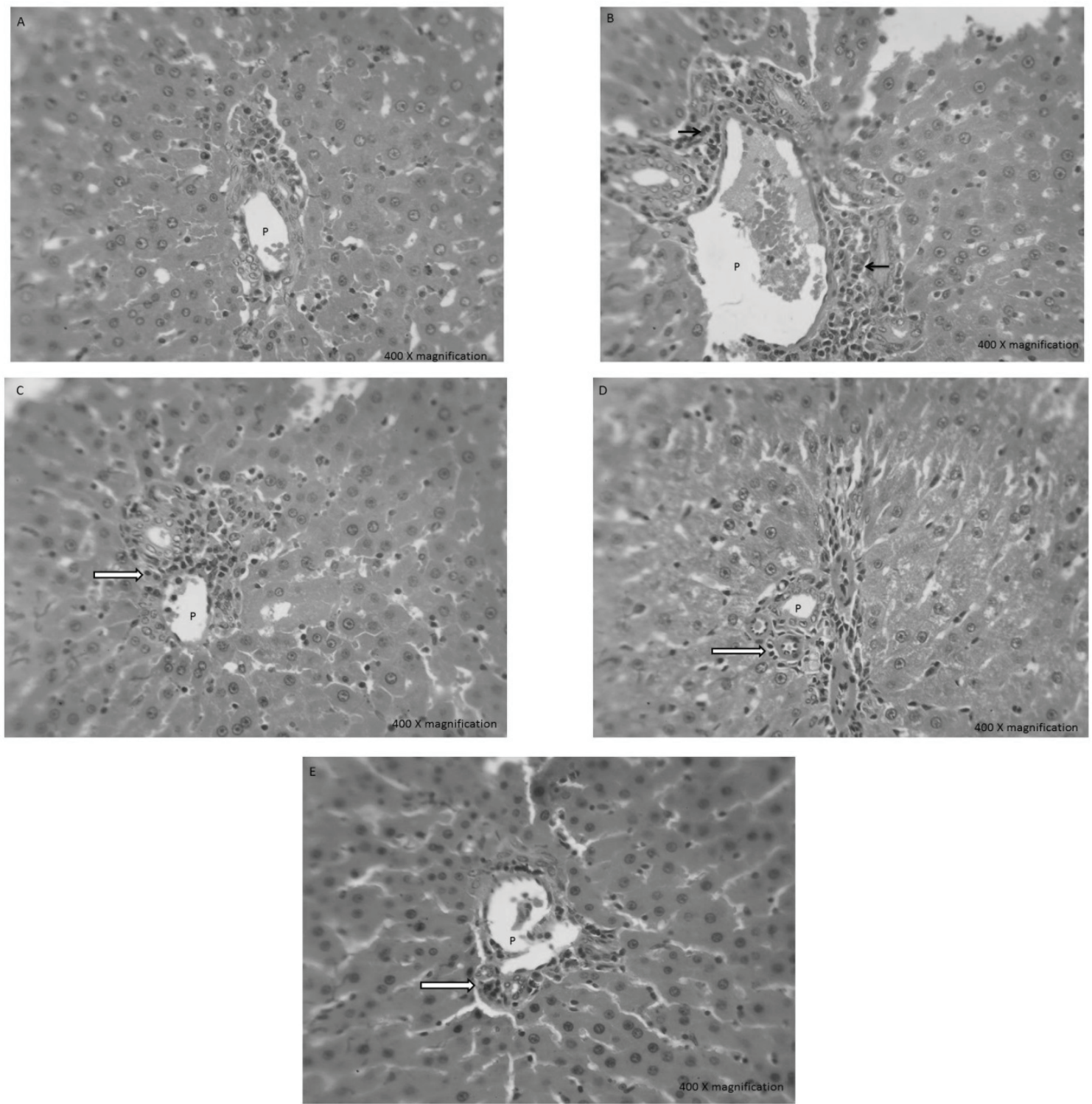

Fig. 1: Photomicrographs of rat liver sections

A: Group 1 showed the image of normal rat liver, stained by haematoxylin and eosin. No inflammation was observed (P denotes periportal region). B: group 2 showed the image of rat liver induced by high-fat diet for $8 \mathrm{w}$ (black arrow indicates the moderate inflammation). C: group 3 showed the image of high fat diet-induced rat liver in co-treatment with ethanol extract of Punica granatum $L$. leaf, $200 \mathrm{mg} / \mathrm{kg}$ (white arrow indicates the mild inflammation). D: group 4 showed the image of high fat diet-induced rat liver in co-treatment with ethanol extract of Punica granatum $L$. leaf, $100 \mathrm{mg} / \mathrm{kg}+\mathrm{gallic}$ acid, $10 \mathrm{mg} / \mathrm{kg}$. E: $\mathrm{showed} \mathrm{the} \mathrm{image} \mathrm{of}$ high fat diet-induced rat liver in co-treatment with orlistat, $22 \mathrm{mg} / \mathrm{kg}$

of lymphocytes, plasma cells and occasional eosinophils, which showed that these treatments were effective in reducing inflammation from moderate to mild and thus has protective effect against inflammation.

In conclusion, the animals fed with HFD for $8 \mathrm{w}$ had altered liver function and increased oxidative stress. HFD produced liver dysfunction could be due to oxidative stress, which caused macrophage infiltration $^{[52]}$. EPGL+GA treatment significantly restored liver function and morphology by reducing oxidative stress. Previous work from this laboratory reported that EPGL has a considerable amount of phenols, flavonoids, tannins and terpenoids ${ }^{[18]}$ and also showed effective in vitro free radical scavenging activity. Even though EPGL has $\mathrm{GA}^{[16]}$, addition of GA in the ratio of 1:10 to EPGL found to be more effective in ameliorating liver and kidney dysfunction and increased the antioxidant content. In conclusion, these results indicated that EPGL+GA has hepatoprotective activity.

\section{Acknowledgements:}

The authors thank Dr. R. Venkataeswari, Assistant Professor, IBMS, University of Madras, Taramani 
Campus for providing the facility to carry out extraction and also thank Dr. R. Selvaraj and his team, Sathyabama University, for their assistance in animal work. The authors wish to acknowledge Dr. P. Jayaraman, Director of National Institute of Herbal Science, Plant Anatomy Research Centre, Chennai for authenticating the plant material.

\section{REFERENCES}

1. Finucane MM, Stevens GA, Cowan MJ, Danaei G, Lin JK, Paciorek CJ et al. National, regional and global trends in body-mass index since 1980: Systematic analysis of health examination surveys and epidemiological studies with 960 country-years and 9.1 million participants. Lancet 2011;377(9765):557-67.

2. Andruszkow H, Veh J, Mommsen P, Zeckey C, Hildebrand F, Frink M. Impact of the body mass on complications and outcome in multiple trauma patients: what does the weight weigh? Mediators Inflamm 2013;2013:345702.

3. Carr RM, Oranu A, Khungar V. Nonalcoholic fatty liver disease: pathophysiological and management. Gastroenterol Clin North Am 2016;45(4):639-52.

4. Fonseca-Alaniz MH, Takada J, Alonso-Vale MI, Lima FB. Adipose tissue as an endocrine organ: From theory to practice. J Pediatr 2007:83(suppl 5):S192-203.

5. Halliwell B, Gutteridge JMC. Free radicals in biology and Medicine. 5th ed. Oxford, United Kingdom: Oxford University Press; 2015.

6. Barrera G. Oxidative stress and lipid peroxidation products in cancer progression and therapy. ISRN Oncol 2012:2012;137289.

7. Noeman SA, Hamooda HE, Baalash AA. Biochemical study of oxidative stress markers in the liver, kidney and heart of high fat diet-induced obesity in rats. Diabetol Metab Syndr 2011;3(1):17.

8. Meng R, Zhu DL, Bi Y, Yang DH, Wang YP. Antioxidative effect of apocynin on insulin resistance in high-fat diet mice. Ann Clin Lab Sci 2011;41(3):236-43.

9. Forouzandeh H, Kalantari H, Saki N, Foruozandeh Z, Arefian E, Farahani A et al. Role of oxidative stress in the liver cancr. Clin Cancer Investig J 2017;6(1):1-9.

10. Yang RL, Li W, Shi YH Le GW. Lipoic acid prevents high-fat diet-induced dyslipidemia and oxidative stress: a microarray analysis. Nutrition 2008;24(6):582-88.

11. Sharma T, Kanwar SS. Phytomolecules for obesity and body weight management. J Biochem Cell Biol 2018;1(1):1-8.

12. Hosoyamada Y, Yamada M. Effects of dietary fish oil and apple polyphenol on the concentration serum lipids and excretion of fecal bile acids in rats. J Nutr Sci Vitaminol 2017;63(1):21-7.

13. Leite AV, Malta LG, Riccio MF, Eberlin MN, Pastore GM, Marostica Junior MR. Antioxidant potential of rat plasma by administration of freeze-dried jaboticaba peel (Myrciaria jaboticaba Vell Berg). J Agric Food Chem 2011;59(6):2277-83.

14. Vanzo A, Vrhovsek U, Tramer F, Mattivi F, Passamonti S. Exceptionally fast uptake and metabolism of cyanidin 3-glucoside by rat kidneys and liver. J Nat Prod 2011;74(5):1049-54.

15. Garachi D, Patel A, Chakraborty M, Kamath JV. Phytochemical and pharmacological profile of Punica granatum: an overview. Int Res J Pharm 2012;3(2):65-8.
16. Sreedevi P, Vijayalakshmi K. Determination of antioxidant capacity and gallic acid content in ethanolic extract of Punica granatum L. leaf. Asian J Pharm Clin Res 2018;11(4):319-23.

17. Subramanian V, Venkatesan B, Tumala A, Vellaichamy E. Topical application of Gallic acid suppresses the 7, 12DMBA/Croton oil-induced two step skin carcinogenesis by modulating anti-oxidants and MMP-2/MMP-9 in Swiss albino mice. Food Chem Toxicol 2014;66:44-55.

18. Sreedevi P, Vijayalakshmi $\mathrm{K}$ and Venkataeswari $\mathrm{R}$. Phytochemical evaluation of Punica granatum L. leaf extract. Int J Curr Pharm Res 2017;9(4):14-8.

19. Kim MS, Kim JK, Kwon DY, Park R. Antiadipogenic effect of Garcinia extract on lipid droplets accumulation and the expression of transcription factor. Biofactors 2004;22(14):193-96.

20. Sreedevi P. Vijayalakshmi K. Acute oral toxicity study of ethanolic extract of Punica granatum (L.) leaves in Zebra fish (Danio rerio). World J Pharm Res 2018;7(9);1058-71.

21. Asker ME, Ali SI, Younis NN, Shaheen MA, Zaher ME. Raspberry ketone versus calorie restriction on modulating metabolic disorders in obese rats. J Mol Cell Biol Forecast 2018;1(2):1-7.

22. Gowri R, Madhavan V. Evaluation of antioxidant activity of ethanolic extract of Sphaeranthus amaranthoides Burm.f. Int J Drug Dev Res 2013;5(4):320-29.

23. Palipoch S, Punusawad C. Biochemical and histological study of rat liver and kidney injury induced by Cisplatin. J Toxicol Pathol 2013;26(3):293-299.

24. Lowry OH, Rosebrough NJ, Farr AL, Randall RJ. Protein measurement with the Folin phenol reagent. J Biol Chem 1951;193(1):265-75.

25. Doumas BT, WatsonWA, Biggs HG. Albumin standards and the measurement of serum albumin with bromocresol green. Clin Chim Acta 1971;31(1):87-96.

26. Rosengren BI, Rippe B, Tenstad O, Wiig H. Acute peritoneal dialysis in rats results in a marked reduction of interstitial colloid osmotic pressure. J Am Soc Nephrol 2004;15(12):3111-6.

27. Reitman S, Frankel S. A colorimetric method for the determination of serum glutamic oxaloacetic and glutamic pyruvic transaminases. Am J Clin Pathol 1957;28(1):56-3.

28. King EJ, Armstrong AR. Convenient method for deterrminig serum and bile phosphatase activity. Can Med Assoc J 1934;31(4):376-81.

29. McCord JM, Fridovich I. Superoxide dismutase. An Enzymic function for erythrocuprein (hemocuprein). J Biol Chem 1969;244(22):6049-55.

30. Goth L. A simple method for determination of serum catalase activity and revision of reference range. Clin Chim Acta 1991;196(2-3):146-52.

31. Moron MS, Depierre JW, Mannervik B. Levels of glutathione, glutathione reductase and glutathione-s-transferase activities in rat lung and liver. Biochim Biophys Acta 1979;582(1):67-78.

32. Ohkawa H, Ohishi N, Yagi K. Assay for lipid peroxides in animal tissues by thiobarbituric acid and reaction. Anal Biochem 1979;95(2):351-8.

33. Camara NO, Iseki K, Kramer H, Liu ZH, Sharma K. Kidney disease and Obesity: epidemiology mechanisms and treatment. Nat Rev Nephrol 2017;13(3):181-90.

34. Shah SS, Shah GB, Singh SD, Gohil PV, Chauhan K, Shah $\mathrm{KA}$, et al. Effect of piperine in the regulation of obesityinduced dyslipidemia in high fat diet rats. Ind $\mathrm{J}$ Pharmacol 2011;43(3):296-9. 
35. Mounika P, Anusha M, Sahoo NK. A review on various approaches on liver reprogramming. Chronicles Pharm Sci 2017;1(2):73-88.

36. Paschos $\mathrm{P}$, Paletos $\mathrm{K}$. Non alcoholic fatty liver disease two-hit process:multifactorial character of the second hit. Hippokratia 2009;13(2):128.

37. Das N, Sikder K, Ghosh S, Fromenty B, Dey S. Moringa oleifera Lam. leaf extract prevents early liver injury and restores antioxidant status in mice fed with high-fat diet. Indian J Exp Biol 2012;50(6):404-12.

38. Ibrahim NL. Study of serum copper and iron in children with chronic liver diseases. Anat Physiol 2013;4(1):1-34.

39. Kasetti RB, Rajasekhar MD, Kondeti VK, Fatima SS, Kumar EG, Swapna S, et al. Antihyperglycemic and antihyperlipidemic activities of methanol: water (4:1) fraction isolated from aqueous extract of Syzgium alternifolium seeds in Streptozotocin-induced diabetic rats. Food Chem Toxicol 2010;48(4):1078-84.

40. Farkaset J, Farkas P, Hyde D. Liver and gastroenterology tests. In: Lee M, editor. Basic skills in interpreting laboratory data. 3rd ed. Bethesda, Maryland: American Society of Health System Pharmacists; 2004.

41. Sena CM, Cipriano MA, Botelho MF, Seiça RM. Lipoic acid prevents High-fat diet-induced hepatic steatosis in Goto Kakizaki rats by reducing oxidative stress through $\mathrm{Nrf} 2$ activation. Int J Mol Sci 2018;19(9):1-14.

42. Shamsoddini A, Sobhani V, Ghamar Chehreh ME, Alavian SM, Zaree A. Effect of aerobic and resistance exercise training on liver enzymes and hepatic fat in Iranian Men with nonalcoholic fatty liver disease. Hepat Mon 2015;15(10):e31434.

43. Buzzetti E, Pinzani M, Tsochatzis EA. The multiple-hit pathogenesis of non-alcoholic fatty liver disease (NAFLD). Metabolism 2016;65(8):1038-48.

44. Arrigo T, Leonardi S, Cuppari C, Manti S, Lanzafame A, Gabriella D'A, et al. Role of the diet as a link between oxidative stress and liver diseases. World $\mathrm{J}$ Gastroenterol 2015;21(2):384-95.

45. Wood LG. Diet, Obesity and Asthma. Ann Am Thorac Soc 2017; 14(suppl 5):332-38.

46. Baunthiyal M, Singh V, Dwivedi S. Insights of antioxidants as molecules for drug discovery. Int J Pharmacol 2017;13(7):87489.

47. Berwal MK, Ram C. Superoxide Dismutase: A stable biochemical marker for abiotic stress tolerance in higher plants. IntechOpen 2018;82079:1-10.

48. Liu Y, Yao Y, Hu X, Xing S, Xu L. Cloning and allelic variation of two novel catalase genes (SoCAT-1 and SsCAT-1) in Saccharum officinarum L. and Saccharum Spontaneum L. Biotechnol Biotechnol Equip 2015;29(3):431-40.

49. Birk J, Meyer M, Aller I, Hansen HG, Odermatt A, Dick TP, et al. Endoplasmic reticulum: reduced and oxidized glutathione revisited. J Cell Sci 2013;126(7):1604-17.

50. Annamalay SD. Effects of anti-oxidants on oxidative stress: Assessing MDA in urine samples. Int $\mathrm{J}$ Clin Nutr Diet 2018;4:1-7.

51. Kumar PS, Asdaq B, Kumar PN, Asad M, Khajuria D. Protective effect of Zizyphus jujuba fruit extract against Paracetamol and Thioacetamide induced hepatic damage in rats. Internet J Pharmacol 2008;7(1):1-9.

52. Alisi A, Carpino G, Oliveira FL, Panera N, Nobili V, Gaudio E. The role of tissue macrophage-mediated inflammation on NAFLD pathogenesis and its clinical implications. Mediators Inflamm 2017;2017: 8162421. 